\section{NSF Notes}

\section{Creativity Awards for Undergraduate Engineering Students}

Thirty-one creative undergraduate engineering students will receive $\$ 30,000$ per year for three years under a new National Science Foundation program initiated to encourage more engineering students to pursue graduate study and research. Each award will fund student research, pay tuition and fees, and provide a stipend of up to $\$ 20,000$. The award will be administered by the university where the student pursues a graduate program and will name the student's graduate faculty sponsor as principal investigator.

The 172 applications were evaluated primarily on the basis of creativity, but other criteria, including undergraduate training and education, research methods, and the significance of the proposed research to the advancement of engineering knowledge were also considered. Panels of engineers in Chicago, Boston, Atlanta, Denver, and San Francisco interviewed 65 finalists, from whom the 31 winners were selected.

The Creativity Awards will be an ongoing program, with another 30 awards planned for 1988. The new program is just one of several that NSF's Engineering Directorate is undertaking to retain talented and creative people in engineering research careers. Other programs include Research Experiences for Undergraduates, Engineering Research Initiation Awards, and Presidential Young Investigators.

\section{Nominations Sought for \\ A.T. Waterman Award}

The NSF Alan T. Waterman Award Committee has issued a call for nominations of candidates for the 13th annual award. Intended to give recognition to an outstanding young researcher in any field of science, mathematics, or engineering and to encourage further high quality research, the award was established by Congress in 1975 to mark the 25th anniversary of the National Science Foundation and to honor the first director of the Foundation, Dr. Waterman.

In addition to a medal, the award recipient receives up to $\$ 500,000$ for up to three years of research or advanced study in the mathematical, physical, medical, biological, engineering, social, or other sciences at the institution of the recipient's choice.

Candidates must be U.S. citizens or permanent residents, up to 35 years old, and not more than five years beyond receipt of the PhD degree by December 31 of the year in which nominated. Candidates should have completed sufficient scientific or engineering research to have demonstrated, through personal accomplishments, outstanding capability and exceptional promise for significant future achievement.
In addition, candidates should exhibit quality, innovation, and potential for discovery in their research.

Nominations for the award may be submitted by scientific and educational communities, individuals, professional societies, industry, and other appropriate organizations. The deadline for nominations for the 1988 award is December 31, 1987. Announcement of the award will be made in May 1988. Six copies of each nomination should be submitted to the Alan T. Waterman Award Committee, National Science Foundation, Washington, DC 20550

For information or a copy of the nomination form, contact the executive secretary for the committee, Mrs. Lois J. Hamaty, National Science Foundation, Washington, DC 20550; (202) 357-7512.

\section{SBIR Awards Made to \\ 151 Small Businesses}

NSF announced 151 grants totaling $\$ 6$ million to small businesses to promote research geared to the development of innovative commercial products and processes. Selected from 1,195 proposals received during a 1986 solicitation, the 151 grants were made through NSF's threephase Small Business Innovation Research (SBIR) Program. The awards are for Phase I research, providing firms with up to $\$ 40,000$ for six months to explore the technical feasibility of promising ideas.

Awards went to 123 firms in 31 states, including 75 first-time recipients. The firms range in size from one to 401 employees. Sixteen companies received more than one award. The most promising projects to emerge from Phase I will receive approxi- mately $\$ 200,000$ from NSF for two years of Phase II research. Private investors will fund Phase III product development, manufacturing, and marketing efforts. SBIR grants were made in the following research categories:

- Physics - 2 awards

- Chemistry - 5 awards

- Mathematical Sciences - 4 awards

- Computer Research -6 awards

- Materials Research - 14 awards

- Cellular Biosciences - 7 awards

- Molecular Biosciences - 5 awards

- Biotic Systems and Resources - 1 award

- Behavioral and Neural Sciences-

2 awards

- Social and Economic Sciences-3 awards

- Information Science and Technology-

2 awards

- Astronomical Sciences - 1 award

- Atmospheric Sciences - 5 awards

- Earth Sciences - 4 awards

- Ocean Sciences -6 awards

- Polar Programs - 2 awards

- Electrical, Computer, and Systems Engineering -16 awards

- Chemical, Biochemical, and Thermal Engineering - 18 awards - Mechanics, Structures, and Materials Engineering18 awards

- Design, Manufacturing, and Computer Engineering - 10 awards

- Emerging and Critical Engineering Systems - 15 awards

- Advanced Scientific Computing5 awards

Copies of the 1987 SBIR solicitation can be obtained from: National Science Foundation, Forms and Publications Office, 1800 G Street NW, Room 232, Washington, DC 20550.

MIR
Have You Moved?

If you have recently moved or changed employers, MRS would like to know your new address so we can keep you up-to-date on all the latest Society activities. Don't miss any of your membership benefits!

\section{Contact:}

Materials Research Society

9800 McKnight Road, Suite 327

Pittsburgh, PA 15237

Telephone (412) 367-3003 